\title{
Penggunaan Pemutih Gigi Mengandung Hidrogen Peroksida 40\% Dibanding dengan Strawberry (Fragaria X ananassa) terhadap Ketebalan Email, Kadar Kalsium, dan Kekuatan Tekan Gigi
}

\author{
Yuniarti, ${ }^{1}$ Achadiyani, ${ }^{2}$ Nani Murniati ${ }^{1}$ \\ ${ }^{1}$ Universitas Islam Bandung, ${ }^{2}$ Universitas Padjadjaran
}

\begin{abstract}
Abstrak
Estetik gigi adalah hal yang penting bagi seseorang. Salah satu hal yang memengaruhi estetik gigi adalah warna gigi. Perubahan warna gigi dapat diperbaiki dengan pemutihan gigi hidrogen peroksida 40\% dan strawberry (Fragaria $x$ ananassa). Penelitian eksperimental laboratoris membandingkan gigi kelompok kontrol dengan dua kelompok perlakuan gigi yang diolesi bahan pemutih gigi hidrogen peroksida 40\% atau direndam dalam strawberry. Penelitian dilakukan di Laboratorium Histologi Fakultas Kedokteran dan Laboratorium Kimia Universitas Padjadjaran, serta Laboratorium ITMKG Fakultas Kedokteran Gigi Universitas Padjadjaran periode Agustus 2012-Mei 2013. Kelompok masing-masing memakai sembilan buah gigi premolar permanen yang diukur ketebalan email secara mikroskopis, kadar kalsium memakai spektrofotometer, dan kekuatan tekan memakai universal testing machine. Uji statistik pengukuran ketebalan email adalah uji-t, pengukuran kadar kalsium memakai Wilcoxon dan Mann Whitney, sedangkan hasil pengukuran kekuatan gigi diuji dengan Kruskal Wallis dan Post Hoc Mann Whitney. Hasil uji penurunan ketebalan email kedua kelompok perlakuan dibandingkan dengan kontrol (uji dependent $t, \mathrm{p}=0,002$ dan $\mathrm{p}=0$,0001) dan perbedaan penurunan ketebalan email antara kedua kelompok (uji independent $\mathrm{p}=0,0375$ ) adalah signifikan. Penurunan kadar kalsium kedua kelompok dibandingkan dengan kontrol (uji Wilcoxon $\mathrm{p}=0,173$ dan $\mathrm{p}=0,441$ ) dan perbedaan kadar kalsium antara kedua kelompok tersebut (uji Mann Whitney $\mathrm{p}=0,480$ ) tidak signifikan. Uji kekuatan tekan gigi signifikan antara kontrol dan dua kelompok perlakuan (uji Kruskall Wallis $\mathrm{p}=0,014$ ), namun bila memakai uji Post Hoc Mann Whitney hanya penurunan kekuatan tekan gigi antara kontrol dan hidrogen peroksida yang berbeda signifikan $(\mathrm{p}=0,02)$. Simpulan, hidrogen peroksida 40\% menurunkan ketebalan email dan kekuatan tekan gigi lebih besar dibanding dengan strawberry, tetapi tidak menurunkan kadar kalsium lebih besar dibanding dengan strawberry.
\end{abstract}

Kata kunci: Hidrogen peroksida 40\%, strawberry (Fragaria $x$ ananassa), ketebalan email, kadar kalsium gigi, kekuatan tekan gigi

\section{Teeth Bleaching Hydrogen Peroxide 40\% Compared with Strawberry (Fragaria $X$ ananassa) to Enamel Thickness, Calcium Level and Compressive Strength of Teeth}

\begin{abstract}
Teeth esthetics is important for someone. One thing influence teeth estheticsis is colour. Dental bleaching using hydrogen peroxide $40 \%$ and strawberry (Fragaria $\mathrm{x}$ ananassa) is conservative alternative to restore the esthetics of either stained teeth. This study was an experimental laboratory by comparing control group with two treatment groups were teeth smeared hydrogen peroxide $40 \%$ or soaked in strawberry. This study was done in Histology Laboratory Faculty of Medicine and Chemical Laboratory Universitas Padjadjaran, and ITMKG Laboratory Faculty of Dentistry Universitas Padjadjaran period August 2012-May 2013. Each group used nine permanent premolars, which will be measured email thickness microscopically, calcium levels using spectrophotometer, and compressive stregth using universal testing machine. The statistical test used for thickness measurement results email was the t-test, for measurement of calcium levels using Wilcoxon test and Mann Whitney while for tooth strength measurements were tested using Kruskal Wallis and Post Hoc Mann Whitney. The results obtained for the test email thickness reduction of both treatment groups compared with the control (test dependent $t, p=0.002$ and $p=0.0001$ ) and a decrease in the thickness difference between the two treatment groups email (independent test, $\mathrm{p}=0.0375$ ) were significant. The results of the impairment test calcium levels both treatment groups compared with controls (Wilcoxon $\mathrm{p}=0.173$ and $\mathrm{p}=0.441$ ), and the difference in calcium levels between the two groups (Mann Whitney test, $\mathrm{p}=0480$ ) was not significant. The results of compressive strength test teeth showed significant gains between the control group and two treatment groups (Kruskall Wallis test, $\mathrm{p}=0.014$ ), However when using Post Hoc Mann Whitney test only decrease the compressive strength of the teeth between the control group and the treatment group were significant hydrogen peroxide $(\mathrm{p}=0.02)$. In conclusions, $40 \%$ hydrogen peroxide causes a decrease in the thickness of the email and the compressive strength is greater than strawberry but do not cause a decrease in blood calcium level greater than strawberry.
\end{abstract}

Key words: 40\% Hydrogen peroxide, strawberry, email thickness, teeth calcium levels, the compressive strength of teeth

Korespondensi: candytone26@gmail.com 


\section{Pendahuluan}

Estetik gigi merupakan hal yang penting bagi seseorang dan penelitian menunjukkan bahwa estetik gigi memengaruhi pada opini seseorang terhadap orang lain ketika pertama kali bertemu. Salah satu keadaan yang memengaruhi estetik gigi adalah warna gigi tersebut. Perubahan warna gigi itu dapat menimbulkan persoalan estetika yang dapat memberikan dampak psikologi yang cukup besar terutama apabila terjadi pada gigi anterior. ${ }^{1,2}$

Pemutihan gigi adalah suatu tindakan untuk menghilangkan pewarnaan yang terjadi pada gigi secara kimiawi dengan bahan oksidator. Bahan dasar yang digunakan untuk pemutihan gigi adalah hidrogen peroksida. ${ }^{3}$ Hidrogen peroksida adalah bahan kimia yang sangat reaktif yang tersusun atas komponen hidrogen dan oksigen. Hidrogen peroksida tersebut dapat memutihkan gigi karena dapat menembus lapisan gigi dan memecah molekul kompleks dari zat-zat yang dapat menyebabkan pewarnaan pada gigi. ${ }^{4} \mathrm{Pada}$ bulan Januari 2008, the European Scientific Committee on Consumer Products atau SCCP kembali mengeluarkan pernyataan bahwa kadar hidrogen peroksida sampai 6\% aman digunakan oleh pasien sebagai bahan pemutih gigi tanpa pengawasan dokter gigi. ${ }^{3}$ Menurut standar zat beracun tahun 2008, hidrogen peroksida dengan kadar 3-6\% disebut sebagai bahan schedule 5 yang artinya harus digunakan dengan hati-hati dan hidrogen peroksida dengan kadar di atas 6\% disebut sebagai bahan schedule 6 yang artinya bahan beracun. ${ }^{5}$ Pada kenyataannya, pemutihan gigi yang dilakukan oleh dokter gigi di tempat praktik menggunakan kadar hidrogen peroksida hingga 40\% dikarenakan keefektifannya dalam menghilangkan pewarnaan gigi. ${ }^{6}$

Beberapa penelitian telah memperlihatkan bahwa proses pemutihan gigi yang menggunakan bahan dasar berupa hidrogen peroksida dapat merusak permukaan email yang meliputi depresi email yang dangkal, juga peningkatan porositas, mengurangi kekerasan email dan erosi email, ${ }^{7-13}$ menyebabkan kalsium hilang dari jaringan keras gigi, dan berkurangnya ketebalan email gigi. ${ }^{14}$

Hidrogen peroksida dapat menjadi bentuk $\mathrm{H}_{4} \mathrm{O}_{4}$ yang ternyata mempunyai kemampuan untuk mengubah struktur hidroksiapatit dan dapat menggantikan $\mathrm{PO}_{4}$ dengan ligan diperoxo membentuk kompleks baru sehingga struktur email menjadi rapuh dan mengurangi kekuatan tekan gigi. ${ }^{13}$

Kinimasyarakat mulaitertarikmenggunakan bahan alami sebagai bahan pemutih gigi karena mudah didapatkan dan lebih ekonomis. Salah satunya mempergunakan strawberry (Fragaria $x$ ananassa). Asam malat di dalam strawberry (Fragaria $x$ ananassa) itu dapat memutihkan gigi dan juga menghilangkan pewarnaan pada gigi, ${ }^{15}$ walaupun terdapat kontradiksi mengenai keamanan penggunaan strawberry (Fragaria $x$ ananassa) sebagai bahan pemutih gigi. ${ }^{16,17}$

Tujuan penelitian ini adalah menganalisis pengaruh penggunaan pemutih gigi mengandung hidrogen peroksida 40\% dibandingkan dengan strawberry (Fragaria $x$ ananassa) terhadap ketebalan email, kadar kalsium, dan kekuatan tekan gigi.

\section{Metode}

Penelitian ini adalah penelitian eksperimental laboratoris dilakukan di Laboratorium Histologi Fakultas Kedokteran dan Laboratorium Kimia Universitas Padjadjaran dan juga Laboratorium ITMKG Fakultas Kedokteran Gigi Universitas Padjadjaran periode Agustus 2012-Mei 2013. Penentuan jumlah sampel menggunakan rumus sampel perbedaan dua rata-rata, didapat jumlah sampel=9 untuk kelompok masing-masing.

Bahan penelitian ini adalah gigi premolar permanen dari pasien yang diekstraksi untuk kepentingan perawatan ortodonti dan juga dari pasien yang giginya avulsi. Buah strawberry (Fragaria xananassa) sebanyak $150 \mathrm{~g}$ diblender tanpa air selama 1 (satu) menit dan diukur $\mathrm{pH}-$ nya $=3,4$ dan dengan bahan pemutih gigi yang mengandung hidrogen peroksida $40 \%$.

Alat yang dipergunakan dalam penelitian ini adalah gergaji untuk pemotong tulang, object glass, mikroskop, gerinda, atomic absorption spektrofotometer (AAS) merk Perkin Elmer, dan alat pengukur kekuatan tekan gigi universal testing machine.

Ketebalan email diukur secara mikroskopis dan pengelompokan gigi dalam dua kelompok. Pada kelompok 1 diberikan perlakuan bahan pemutih yang mengandung hidrogen peroksida 40\%, sedangkan pada kelompok 2 diberikan strawberry (Fragaria $x$ ananassa). Mahkota gigi pada setiap kelompok dibagi menjadi dua bagian secara vertikal. Bagian pertama dibiarkan tanpa perlakuan (kontrol), sedangkan bagian kedua menerima perlakuan. Bagian perlakuan pada kelompok 1 akan diaplikasikan hidrogen 
peroksida $40 \%$ setebal $1 \mathrm{~mm}$ selama 20 menit pada hari ke-o, -3 , dan -6 . Bagian perlakuan kelompok 2 akan direndam dalam strawberry (Fragaria $x$ ananassa) yang telah diblender tanpa menggunakan air selama 5 menit, $3 \mathrm{x}$ / hari selama 2 minggu. Setiap mahkota gigi dari setiap kelompok dibuat preparat histologi sediaan gigi gosok. Dibandingkan berapa $\mathrm{mm}$ email yang hilang dari setiap gigi (dibandingkan antara kontrol dan bagian yang diberikan perlakuan), kemudian dibandingkan kelompok mana yang memperlihatkan hilangnya email gigi terbesar \{antara kelompok 1 yang diberikan perlakuan hidrogen peroksida atau kelompok 2 yang diberi perlakuan strawberry (Fragaria $x$ ananassa)\}.

Setiap email gigi setiap kelompok kontrol dan perlakuan diambil dalam jumlah yang sama banyak dan kemudian dihaluskan. Setiap gigi yang sudah dihaluskan tersebut didestruksi kering menggunakan oven dengan suhu $300^{\circ} \mathrm{C}$ kemudian diekstrak menggunakan $\mathrm{HNO}_{3} 6,5 \%$ sebanyak $10 \mathrm{~mL}$, dipanaskan di dalam hotplate selama 5 (lima) menit dan kemudian disaring ke dalam labu ukur, selanjutnya kadar kalsium email kelompok kontrol dan perlakuan diukur menggunakan spektrofotometer. Dibandingkan kelompok penelitian yang mana memperlihatkan penurunan kadar kalsium yang terbesar antara kelompok 1 yang diberikan perlakuan hidrogen peroksida dan kelompok 2 yang diberi perlakuan strawberry (Fragaria $x$ ananassa)\}.

Pengukuran kekuatan tekan gigi dilakukan dengan mengelompokkan gigi tersebut dalam 3 (tiga) kelompok. Kelompok 1 diberi perlakuan bahan pemutih yang mengandung hidrogen peroksida $40 \%$ setebal $1 \mathrm{~mm}$ selama 20 menit pada hari ke-o, -3, dan -6. Kelompok 2 direndam di dalam strawberry (Fragaria $x$ ananassa) yang telah diblender tanpa mempergunakan air selama 5 menit, 3x/hari selama 2 minggu dan kelompok 3 sebagai kontrol. Setiap gigi baik pada kelompok kontrol maupun kelompok perlakuan ditanam dalam self curing acrylic dengan posisi pemukaan buka menghadap ke atas. Setiap gigi baik kelompok kontrol maupun kelompok perlakuan diukur kekuatan giginya menggunakan úniversal testing machine. Cara pemakaiannya adalah dengan meletakkan gigi yang sudah ditanam dalam self curing acrylic di bawah bor penekanan yang terdapat pada universal testing machine itu, kemudian alat dinyalakan, bor penekan akan turun perlahanlahan menuju permukaan gigi premolar dengan kecepatan $0,5 \mathrm{~mm} /$ menit. Hasil pengukuran kekuatan tekanan gigi akan terlihat pada layar komputer. Dibandingkan kelompok manakah yang dapat menunjukkan penurunan kekuatan tekanan gigi yang terbesar \{antara kelompok yang diberi perlakuan hidrogen peroksida $40 \%$ dan kelompok yang diberi perlakuan strawberry (Fragaria $x$ ananassa)\}.

\section{Hasil}

Menurunnya ketebalan email (Tabel 1) terjadi pada kelompok perlakuan pemberian hidrogen peroksida $40 \%(0,75 \pm 0,13 \mathrm{~mm})$ dibandingkan dengan kelompok kontrol $(0,91 \pm 0,17 \mathrm{~mm})$. Demikian pula halnya penurunan ketebalan email (Tabel 2) terjadi pada kelompok perlakuan pemberian strawberry (Fragaria $x$ ananassa) $(0,88 \pm 0,18 \mathrm{~mm})$ dibanding dengan kelompok kontrol $(0,97 \pm 0,18 \mathrm{~mm})$.

Hasil perbedaan penurunan ketebalan email rata-rata antara kelompok perlakuan hidrogen peroksida $40 \%$ dan strawberry (Fragaria $x$ ananassa) menunjukkan hasil yang signifikan ( $\mathrm{p}=0,0375$; Tabel 3). Pada kelompok perlakuan strawberry (Fragaria $x$ ananassa) (Tabel 4) didapatkan perubahan kadar kalsium gigi yang tidak signifikan antara kelompok kontrol dan kelompok perlakuan $(\mathrm{p}=\mathrm{0}, 441)$, demikian pula pada kelompok perlakuan pemberian hidrogen peroksida 40\% (Tabel 5) didapatkan perubahan kadar kalsium yang tidak berbeda signifikan kelompok kontrol dengan kelompok perlakuan

\section{Tabel 1 Perbedaan Ketebalan Email Rata-rata Sebelum dengan Sesudah Pemberian} Perlakuan Hidrogen Peroksida 40\%

\begin{tabular}{lccc}
\hline \multicolumn{1}{c}{ Kelompok Perlakuan } & n & Mean \pm SD $(\mathbf{m m})$ & Nilai p \\
\hline Kontrol & 9 & $0,91 \pm 0,17$ & \multirow{0}{*}{$002^{*}$} \\
Perlakuan & 9 & $0,76 \pm 0,13$ & \\
\hline
\end{tabular}

*Uji dependent-t 
Tabel 2 Perbedaan Ketebalan Email Rata-rata Sebelum dengan Sesudah Pemberian Perlakuan Strawberry (Fragaria x ananassa)

\begin{tabular}{cccc}
\hline Kelompok Perlakuan & n & Mean \pm SD (mm) & Nilai p \\
\hline Kontrol & 9 & $0,97 \pm 0.18$ & \\
Perlakuan & 9 & $0,88 \pm 0.18$ & $0,0001^{*}$ \\
\hline
\end{tabular}

*Uji dependent

$(\mathrm{p}=0,173)$.

Terdapat juga perbedaan penurunan kadar kalsium gigi rata-rata (Tabel 6) antara kelompok kontrol dan pemberian hidrogen peroksida 40\% (11.855,55 $\pm 22.308,97 \mathrm{ppm})$ dengan penurunan kadar kalsium gigi rata-rata antara kelompok kontrol dan pemberian strawberry (Fragaria

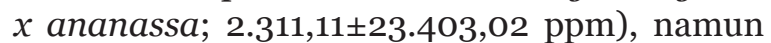
hasil uji statistik mempergunakan uji MannWhitney tidak memperlihatkan hasil signifikan $(\mathrm{p}=\mathrm{o}, 480)$.

Penurunan kekuatan tekan gigi (Tabel 7) terjadi pada kelompok yang diberikan perlakuan kelompok perlakuan $(\mathrm{p}=0,014)$. Pada analisis lanjut menggunakan uji statistik Post Hoc Mann Whitney (lihat Gambar) ditemukan perbedaan yang signifikan kekuatan tekan gigi rata-rata antara kelompok kontrol dibandingkan dengan kelompok perlakuan hidrogen peroksida 40\% $(\mathrm{p}=\mathrm{O}, \mathrm{O} 2)$, namun tidak ditemukan perbedaan kekuatan tekan gigi rata-rata yang signifikan kelompok kontrol dengan kelompok perlakuan strawberry (Fragaria $x$ ananassa) $(\mathrm{p}=0,58)$. Demikian pula perbedaan kekuatan tekan gigi rata-rata antara kelompok perlakuan hidrogen peroksida 40\% dan strawberry (Fragaria $x$

Tabel 3 Perbedaan Ketebalan Email Rata-rata Kelompok Perlakuan Srawberry Fragaria $x$ ananassa) dengan Hidrogen Peroksida 40\%

\begin{tabular}{lccc}
\hline Kelompok Perlakuan & n & Mean \pm SD (mm) & Nilai p \\
\hline Strawberry & 9 & $0,085 \pm 0,028$ & $0,0375^{*}$ \\
Hidrogen peroksida & 9 & $0,155 \pm 0,100$ & \\
\hline
\end{tabular}

*Uji independent $t$

hidrogen peroksida sebesar $155,43 \pm 45,27 \mathrm{MPa}$ dan pada kelompok yang diberikan perlakuan strawberry $(168,88 \pm 60,51 \mathrm{MPa})$ bila dibanding dengan kekuatan tekan gigi kelompok kontrol

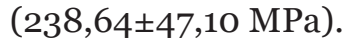

Perubahan kekuatan tekan gigi kelompok kontrol dengan kelompok perlakuan tersebut di atas kemudian dibuktikan dengan uji Kruskall Wallis, didapatkan perubahan kekuatan tekan gigi yang signifikan antara kelompok kontrol dan ananassa) tidak berbeda signifikan dengan uji statistik Post Hoc Mann Whitney ( $\mathrm{p}=0,895)$.

\section{Pembahasan}

Hidrogen peroksida dan strawberry (Fragaria $x$ ananassa) ini selain dapat memutihkan gigi secara efektif, keduanya dapat menimbulkan efek negatif berupa penurunan ketebalan email gigi (Tabel 1 dan 2). Pada penggunaan hidrogen

Tabel 4 Perbedaan Kadar Kalsium Rata-rata Sebelum dengan Sesudah Pemberian Perlakuan Strawberry

\begin{tabular}{lccc}
\hline Kelompok Perlakuan & n & Mean \pm SD $(\mathbf{p p m})$ & Nilai p \\
\hline Kontrol & 9 & $65.955,55 \pm 17.629,45$ & \\
Perlakuan & 9 & $63.644,44 \pm 14.183,09$ & $0,441^{*}$ \\
\hline
\end{tabular}

*Uji Wilcoxon 
Penggunaan Pemutih Gigi Mengandung Hidrogen Peroksida 40\% Dibanding dengan Strawberry (Fragaria X Ananassa) 11 terhadap Ketebalan Email, Kadar Kalsium, dan Kekuatan Tekan Gigi

Tabel 5 Perbedaan Kadar Kalsium Rata-rata Sebelum dengan Sesudah Pemberian Perlakuan Hidrogen Peroksida 40\%

\begin{tabular}{cccc}
\hline Kelompok Perlakuan & n & Mean \pm SD $(\mathbf{p p m})$ & Nilai $\mathbf{p}$ \\
\hline Kontrol & 9 & $71.633,33 \pm 5.833,30$ & \multirow{0}{*}{, $173^{*}$} \\
Perlakuan & 9 & $59.777,77 \pm 22.840,52$ & \\
\hline
\end{tabular}

*Uji Wilcoxon

Tabel 6 Perbedaan Selisih Kadar Kalsium Rata-rata Sebelum dengan Sesudah Perlakuan Kelompok Perlakuan Strawberry (Fragaria $x$ ananassa) dengan Hidrogen Peroksida 40\%

\begin{tabular}{llcc}
\hline Kelompok Perlakuan & n & Mean \pm SD $(\mathbf{p p m})$ & Nilai p \\
\hline Strawberry & 9 & $2.311,11 \pm 23.403,02$ & \\
Hidrogen peroksida & 9 & $11.855,55 \pm 22.308,97$ & $0,480^{*}$ \\
\hline
\end{tabular}

*Uji independent- $t$

peroksida sebagai bahan pemutih gigi dalam penelitian ini, hidrogen peroksida akan berdifusi melalui matriks organik dari email dan dentin. Radikal bebas bermuatan merupakan radikal yang tidak stabil dan mampu bereaksi dengan molekul organik atau radikal bebas yang lainnya terutama molekul-molekul zat warna di dalam gigi setelah zat warna dirusak sehingga terjadi efek pemutihan. $\mathrm{O}_{\mathrm{n}}$ itu dapat bereaksi dengan hidroksiapatit pada gigi dengan reaksi:

$$
\mathrm{Ca}_{10}\left(\mathrm{PO}_{4}\right)_{6}(\mathrm{OH})_{2}+\mathrm{O}_{\mathrm{n}} \rightarrow 10 \mathrm{CaO}+3 \mathrm{P}_{2} \mathrm{O}_{5}+\mathrm{H}_{2} \mathrm{O}
$$

Reaksi oksigenase dengan hidroksiapatit gigi dapat meyebabkan deposit $\mathrm{CaO}$. Deposit $\mathrm{CaO}$ dapat menimbulkan warna putih pada gigi ${ }^{18,19}$ namun selain itu hidrogen peroksida tersebut juga dapat menjadi bentuk diperoxo $\left(\mathrm{H}_{4} \mathrm{O}_{4}\right)$, yang memiliki kemampuan untuk mengubah struktur hidroksiapatit dan mampu menggantikan $\mathrm{PO}_{4}$ dengan ligan diperoxo membentuk kompleks yang baru sehingga dapat menyebabkan struktur email akan menjadi rapuh. ${ }^{13,20}$ Hasil penelitian Hunsaker dan Christensen ${ }^{21}$ serta juga Haywood dkk. ${ }^{22}$ menyatakan bahwa hidrogen peroksida mampu untuk menghilangkan lapisan dentin dan sedikit lapisan email. Kandungan asam malat yang terdapat di dalam strawberry (Fragaria $x$ ananassa) dapat memutihkan gigi. ${ }^{15}$ Secara kimia, asam adalah zat yang dalam air dapat menghasilkan ion hidrogen $(\mathrm{H}+)$. Asam akan terionisasi menjadi ion hidrogen dan ion sisa asam yang bernuatan negatif. Beberapa asam yang dijumpai dalam kehidupan sehari-hari di antaranya asam malat. Sifat dasar asam adalah korosif, bereaksi dengan logam membentuk $\mathrm{H}_{2}$, memiliki rasa asam, dan menghasilkan ion $\mathrm{H}^{+}$dalam air. ${ }^{23}$ Reaksi yang terjadi antara asam malat dan zat penyebab pewarnaan pada gigi adalah reaksi oksidasi asam malat melepaskan elektron yang mampu berikatan dengan zatzat yang menyebabkan perubahan warna pada email itu. Perbedaan kelektronegatifan antara $\mathrm{O}$ dan $\mathrm{H}^{+}$pada gugus $\mathrm{OH}^{-}$yang lebih besar jika dibandingkan dengan $\mathrm{CO}^{-}$dan $\mathrm{OH}^{-}$pada gugus $\mathrm{COOH}$ dan menyebabkan gugus $\mathrm{OH}^{-}$akan lebih mudah putus dan menghasilkan radikal $\mathrm{H}^{+}$. Radikal $\mathrm{H}^{+}$yang terbentuk kemudian berikatan

\section{Tabel 7 Hasil Pengukuran Kekuatan Tekan Gigi}

\begin{tabular}{lccccc}
\hline \multicolumn{1}{c}{$\begin{array}{c}\text { Kelompok } \\
\text { Perlakuan }\end{array}$} & n & $\begin{array}{c}\text { Mean } \pm \text { SD } \\
(\mathbf{M P a})\end{array}$ & $\begin{array}{c}\text { Minimum } \\
(\mathbf{M P a})\end{array}$ & $\begin{array}{c}\text { Maksimum } \\
(\mathbf{M P a})\end{array}$ & Nilai p \\
\hline Hidrogen peroksida & 9 & 138,27 & 82,57 & 208,16 & \\
Strawberry & 9 & 173,95 & 114,15 & 284,50 & $0,014^{*}$ \\
Kontrol & 9 & 237,59 & 127,60 & 288,18 & \\
\hline
\end{tabular}

*Uji Kruskal Wallis 


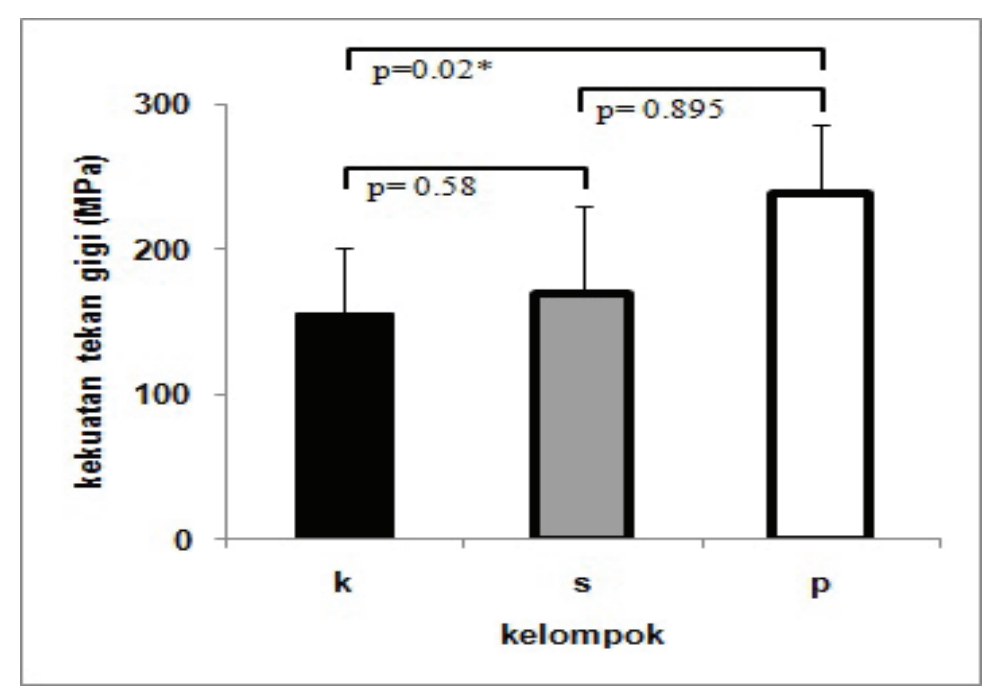

\author{
Gambar Penurunan Kekuatan Tekan Gigi Rata-rata antara Kelompok Kontrol, Kelompok \\ Perlakuan Pemberian Hidrogen Peroksida 40\%, dan Kelompok Perlakuan Pemberian \\ Strawberry (Fragaria $x$ ananassa) \\ Keterangan:

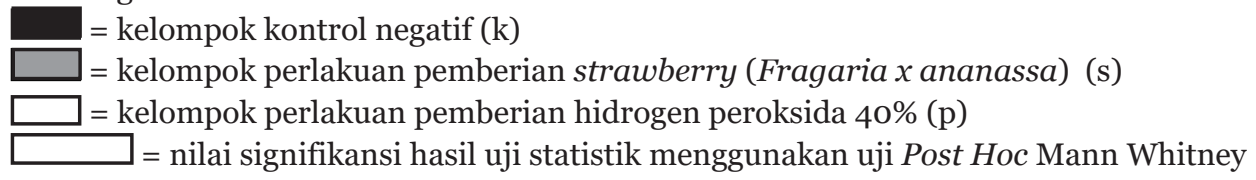

dengan 3 (tiga) molekul $\mathrm{C}$ tersier yang terdapat pada email gigi yang mengalami diskolorasi. Ikatan ini mengakibatkan gangguan konjugasi elektron dan perubahan penyerapan energi pada molekul organik email sehingga terbentuk molekul organik email dengan struktur yang tidak jenuh. Setelah radikal $\mathrm{H}+$ dilepaskan, asam malat melepaskan 4 radikal $\mathrm{OH}$ - yang dapat mengganggu struktur tidak jenuh dari email tersebut menjadi struktur jenuh dengan warna lebih terang. ${ }^{24}$ Selain dapat memutihkan gigi, ternyata strawberry (Fragaria xananassa) dapat menyebabkan erosi gigi. ${ }^{16,17}$

Hilangnya jaringan keras gigi dapat berarti pula sebagai proses demineralisasi yang artinya merupakan suatu proses hilangnya mineral dari struktur gigi. ${ }^{25}$ Pada lingkungan yang netral, kristal hidroksiapatit $\left\{\mathrm{Ca}_{10}\left(\mathrm{PO}_{4}\right)_{6}(\mathrm{OH})_{2}\right\}$ dari email gigi seimbang dengan lingkungan saliva yang tersaturasi dengan ion $\mathrm{Ca}^{2+}$ dan $\mathrm{PO}^{3-}$.

Hidroksiapatit $\left\{\mathrm{Ca}_{10}\left(\mathrm{PO}_{4}\right)_{6}(\mathrm{OH})_{2}\right\}$ bersifat reaktif terhadap ion hidrogen dengan $\mathrm{pH} \leq 5,5$ yang merupakan $\mathrm{pH}$ kritis untuk hidroksiapatit $\left\{\mathrm{Ca}_{10}\left(\mathrm{PO}_{4}\right)_{6}(\mathrm{OH})_{2}\right\}$, pH strawberry (Fragaria $x$ ananassa) yang digunakan dalam penelitian ini adalah 3,4. $\mathrm{H}^{+}$bereaksi dengan kelompok fosfat di dalam lingkungan saliva yang dekat dengan permukaan kristal secara cepat. Proses ini dapat dideskripsikan sebagai konversi $\mathrm{PO}_{4}{ }^{2-}$ menjadi $\mathrm{HPO}_{4}^{2-}$ dengan tambahan $\mathrm{H}^{+}$dan pada waktu yang bersamaan $\mathrm{H}^{+}$mengalami buffering . $\mathrm{HPO}_{4}{ }^{2-}$ ini kemudian tidak dapat berkontribusi terhadap keseimbangan hidroksiapatit normal sehingga kristal hidroksiapatit larut. ${ }^{26}$ Kelarutan hidroksiapatit meningkat 10 kali lipat ketika berada di bawah $\mathrm{pH}$ kritis. ${ }^{27}$

Pada penggunaan hidrogen peroksida 40\% sebagai bahan pemutih gigi dalam penelitian ini menunjukkan penurunan kadar kalsium antara kontrol dan bagian gigi yang diberi perlakuan, namun secara statistik hasilnya tidak signifikan (Tabel 4 dan 5). Berdasarkan teori dinyatakan radikal bebas yang dihasilkan oleh hidrogen peroksida bereaksi dengan substansi organik dan tidak akan berpengaruh terhadap substansi inorganik, namun pada penelitian yang telah dilaksanakan oleh Ogiwara dkk. ${ }^{28}$ dinyatakan bahwa ada efek hidrogen peroksida terhadap substansi inorganik walaupun nilainya sangat kecil. Keadaan ini juga sesuai dengan penelitian sebelumnya ${ }^{29}$ yang menunjukkan penggunaan hidrogen peroksidasebagaibahan untukpemutih gigi menyebabkan perubahan kadar kalsium, fosfat, sulfur dan juga kalium, namun penurunan 
kadar tersebut lebih signifikan tampak pada sementum dan dentin bila dibanding dengan email. ${ }^{30}$ Pada penelitian ini juga menguji efek penggunaan strawberry (Fragaria $x$ ananassa) sebagai bahan pemutih gigi terhadap kadar kalsium gigi, hasilnya menunjukkan penurunan dibandingkan dengan kontrol negatif, namun secara statistik hasilnya tidak signifikan (Tabel 6). Strawberry (Fragaria $x$ ananassa) tersebut mengandung asam malat dengan $\mathrm{pH}$ sebesar 3,4 . Hidroksiapatit email dalam suasana asam akan larut menjadi $\mathrm{Ca}^{2+}$; $\mathrm{PO}_{4}^{-9}$ dan $\mathrm{OH}^{-}$. Ion $\mathrm{H}^{+}$akan beraksi dengan gugus $\mathrm{PO}_{4}^{-9}$, atau $\mathrm{OH}$ membentuk $\mathrm{HSO}_{4}, \mathrm{H}_{2} \mathrm{SO}^{4-}$ atau $\mathrm{H}_{2} \mathrm{O}$, sedangkan yang kompleks terbentuk $\mathrm{CaHSO}_{4}, \mathrm{CaPO}_{4}$ dan $\mathrm{CaHPO}_{4}{ }^{30}$. Terdapat dua alasan mengapa terjadi peningkatan kelarutan email di dalam asam, yaitu 1) ion hidrogen akan melepas ion hidroksil membentuk air dengan reaksi $\mathrm{H}^{+}+\mathrm{OH}^{-} \leftrightarrow \mathrm{H}_{2} \mathrm{O}$ sehingga ketika ion $\mathrm{H}^{+}$meningkat pada kondisi asam maka ion $\mathrm{OH}^{-}$dari kristal hidroksiapatit email yang terdemineralisasi akan menurun karena diikat oleh $\mathrm{H}^{+}$dari asam tersebut, 2) fosfat inorganik yang terdemineralisasi dari kristal hidroksiapatit email pada cairan asam akan terdapat dalam 4 bentuk, yaitu $\mathrm{H}_{3} \mathrm{PO}_{4}, \mathrm{H}_{2} \mathrm{PO}_{4}$, $\mathrm{HPO}_{4}^{2-}$, dan $\mathrm{PO}_{4}^{3-}$, namun pada $\mathrm{pH}^{3}$ kurang dari 4 fosfat inorganik dalam bentuk $\mathrm{PO}_{4}{ }^{3-}$ sehingga pada kondisi asam konsentrasi kalsium tidak terpengaruh, sedangkan konsentrasi $\mathrm{OH}^{-}$dan $\mathrm{PO}_{4}{ }^{3-}$ akan menurun. ${ }^{22}$ Demineralisasi enamel gigi adalah kerusakan hidroksi apatit gigi yang merupakan komponen utama enamel akibat proses kimia. Kondisi deminera1isasi enamel terjadi bila $\mathrm{pH}$ larutan di sekeliling permukaan enamel lebih rendah dari 5,5 (pH larutan strawberry dalam penelitian ini adalah 3,4 ) dan konsentrasi asam yang tidak berdisosiasi itu lebih tinggi di permukaan email daripada konsentrasi asam di dalam email. Demineralisasi email terjadi melalui proses difusi, yaitu proses perpindahan molekul atau ion yang larut dalam air ke atau dari dalam email ke saliva (bila dalam rongga mulut) karena ada perbedaan konsentrasi keasaman minuman di permukaan dengan di dalam email gigi. Mengingat bahwa kalsium merupakan komponen utama dalam struktur gigi dan demineralisasi email terjadi akibat lepasan ion kalsium dari email gigi maka pengaruh asam pada email gigi merupakan reaksi penguraian. Demineralisasi yang terusmenerus akan membentuk pori-pori yang kecil atau porositas pada permukaan email yang sebelumnya tidak ada.

Penelitian yang dilaksanakan sebelumnya menunjukkan bahwa kerusakan email terjadi setelah proses aplikasi topikal dari hidrogen peroksida, kerusakan tersebut berupa pelepasan substansi organik dan inorganik dari email serta penurunan kekerasan email..$^{31}$ Penurunan kekerasan email tersebut berhubungan dengan penurunan kekuatan tekan email yang akhirnya akan memengaruhi penurunan kekuatan tekan gigi secara keseluruhan. ${ }^{32}$ Pengaruh hidrogen peroksida terhadap rusaknya substansi organik email gigi menyebabkan permeabilitas email meningkat dan penurunan resistensi terhadap fraktur yang dapat diasumsikan sama dengan penurunan kekuatan tekan gigi itu. ${ }^{31}$ Demikian pula halnya pada penelitian sebelumnya yang dilakukan Anghel dkk.33 menunjukkan bahwa penurunan kekuatan tekan gigi pada gigi yang telah mengalami pemutihan gigi menggunakan hidrogen peroksida. Hasil penelitian pengukuran kekuatan tekan gigi setelah aplikasi strawberry (Fragaria $x$ ananassa) tidak signifikan sesuai dengan teori bahwa demineralisasi gigi terjadi lebih rendah akibat asam malat dibandingkan dengan asam laktat, asam sitrat, asam oksalat, dan asam fosfat sehingga dapat diasumsikan bahwa penggunaan strawberry (Fragaria $x$ ananassa) sebagai bahan pemutih gigi tidak begitu besar pengaruhnya terhadap penurunan kekuatan tekan gigi. ${ }^{34}$

Sebagai simpulan, hidrogen peroksida $40 \%$ mampu mengakibatkan penurunan ketebalan email dan kekuatan tekan gigi yang lebih besar dibanding dengan strawberry dan hidrogen peroksida 40\% tidak menurunkan kadar kalsium lebih besar dibanding dengan strawberry.

\section{Ucapan Terima Kasih}

Ucapan terima kasih disampaikan kepada staf Laboratorium Histologi Fakultas Kedokteran Universitas Padjajaran (Unpad), Laboratorium Kimia Unpad, dan juga Laboratorium ITMKG FKG Unpad sehingga penelitian ini berhasil diselesaikan.

\section{Daftar Pustaka}

1. Joiner A. The bleaching of teeth: a review of the literature. J Dentistry. 2006;34:412-9.

2. Sagel AP. A person's smile is their first point of communication,so you want that smile to 
14 Penggunaan Pemutih Gigi Mengandung Hidrogen Peroksida 40\% Dibanding dengan Strawberry (Fragaria X Ananassa) terhadap Ketebalan Email, Kadar Kalsium, dan Kekuatan Tekan Gigi

sparkle. $P \& G$ oral care science.1-3.

3. American Dental Association. Tooth whitening/bleaching: treatment considerations for dentists and their patients. 2009 September:1-5.

4. Scientific Committee on Consumer Products. Tooth whiteners \& oral hygiene product scientific committes. Greenfact. 2008:1-3.

5. Australian Dental Association. Community oral health promotion: teeth whitening (bleaching) by persons other than dental care providers. 2009:1-5.

6. American Dental Association. Statement on the safety and effectiveness of tooth whitening product. 2012:1-4.

7. Scientific Committee on Consumer Product. Tooth whiteners \& oral hygiene product containing hydrogen peroxide. Greenfact. 2007:1-17.

8. Goldberg M, Grootveld M, Lynch E. Undesirable and adverse effects of toothwhitening products: a review. J Clin Oral Invest. 2010;14:1-10.

9. Arruda AM, Santos PHD, Sundfeld RH, Berger SB, Briso ALF. Effect hydrogen peroxide at $35 \%$ on the morphology of enamel and interefrence in the de-remineralization process: an in situ study. Operat Dentistry in-press. 2011:1-6.

10. Pinto FC, Oliveira RD, Cavalli V, Giannini M. Peroxide bleaching agent effect on enamel surface microhardness, roughness, and morphology. Braz Oral Res. 2004;18(4):306-11.

11. Ferreira IA, Lopes GC, Vieira LCC, Araujo E. Effect of hydrogen peroxide based home bleaching agents on enamel hardness. Brazil J Oral Sci. 2006;5(18):1090-2.

12. Higgins J, Lotha G, Pallardy L. Encyclopedia brittanica online tooth. 2008:2-5.

13. Bistey T, Hegedus C, Jenei A. Examination of the effect of peroxides on human enamel structure (doctoral dissertation). Debrecen: University of Debrecen, Medical and Health Science Faculty of Dentistry Department of Prosthetic Dentistry; 2008.

14. Tezel H, Ertas SO, Ozata F, Dalgar H, Korkut Z. Effect of bleaching agent on calcium loss from the enamel surface. Quintessence Int. 2007;38(4):339-47.

15. Neilson C. How'd they do that?. Bloomington Dental. 2011:1-4.

16. Santoso P. Kekerasan enamel setelah aplikasi gel karbamid perioksida 10\% dan pasta buah strawberry (penelitian eksperimental laboratoris). Surabaya: Airlangga University Library; 2009.

17. Hapsari, Nalurita. Pengaruh konsentrasi jus buah strawberry sebagai bahan pembersih pada gigi yang direndam larutan kopi (penelitian eksperimental laboratoris). Surabaya. Airlangga University Library; 2008.

18. Moore KL, Persaud TVN, Torchia MG. The developing human. Clinical oriented embryology. Philadelphia: Elsevier; 2011.

19. Budi AT. The combination of sodium perborate and water as intracoronal teeth bleaching agent. Media Dental J. 2008;41(4):187-9.

20. Dawes C. What is the critical PH and why does a teeth dissolve in acid?. J Canadian Dental Association. 2003;69(11):722-3.

21. Hunsaker KJ, Christensen GJ. Tooth bleaching chemicals-influence on teeth and restorations. J Dental Research. 1990;69:303.

22. Haywood VB, Houck V, Heymann HD. Night guard vital bleaching: effect of varrying $\mathrm{pH}$ solutions on enamel surface, texture and color change. Quint Int. 1991;22:775-82.

23. Lower SK. Chem 1 general chemistry reference test. 1999.

24. Margaretha, Rianti, Meizarini. Perubahan warna enamel gigi setelah aplikasi pasta buah stroberi dan gel karbamid peroksida 10\%. Material Dental J. 2009;1(1):16-20.

25. Avery JK. Oral development and histology. New York: Thieme; 2002.

26. Johansson AK, Omar R, carlsson GE, Johansson A. Dental erosion and its growing importance in clinical practise: from past to present.1-5

27. Haywood VB, Leech T, Heymann HD. Night guard vital bleaching: effect on enamel surface texture and diffusion. 1990;21:8014 .

28. Ogiwara M, Miake Y, Yanagisawa T. Changes in dental enamel crystal by bleaching. J Hard Tissue Biol. 2008;17(1):15.

29. Craig BJ, Supeene L. Tooth whitening: efficacy, effect and biology safety. Probe Sci J. 1999;33(6):170.

30. Prasetyo. Keasaman minuman ringan menurunkan kekerasan permukaan gigi. Dental J. 2005;38(2):60-3.

31. Dutra RA, Branco JR, Alvim HH, Poletto LT, 
Penggunaan Pemutih Gigi Mengandung Hidrogen Peroksida 40\% Dibanding dengan Strawberry (Fragaria X Ananassa) 15 terhadap Ketebalan Email, Kadar Kalsium, dan Kekuatan Tekan Gigi

Abuquerque RC. Effect of hydrogen peroxide topical application on the enamel and composite resin surface and interface. Indian J Dental Research. 2009;20(1):65.

32. Manappallil JJ. Basic dental material. Jaypee. 2003;2:92-4.
33. Anghel M, Nica LMD, Valceanu A, Faur N. The compressive strength of bleached teeth. TMJ. 2004;54(1):74.

34. Lussi A, Jaeggi T. Erosion-diagnosis and risk factors. Clin Oral Invest. 2008;12:5-13. 